\title{
MANAJEMEN PENDIDIKAN PESANTREN MODERN DALAM PEMBENTUKAN KARAKTER ANAK: \\ Studi Kasus Pada Pondok Pesantren Modern Diniyyah Pasia Kabupaten Agam
}

\section{Deded Sulaiman}

Guru Pondok Pesantren Diyyah Pasia Kabupaten Agam, Alamat: Galogadang-Andaleh Kecamatan Luhak Kabupaten Lima Puluh Kota, HP. 081363202522

$+2$

\begin{abstract}
Management Education Modern Islamic School in Kids Character Building: Case Studies in Modern Islamic Boarding Diniyyah Pasia Agam Regency. The issues raised in this paper is: How Management Education In Modern Islamic School Character Building Children?

This research is a field of research by using qualitative approach. In these investigations the data to be collected is Pesantren Education Management Modern about Diniyyah Pasia Agam Regency of West Sumatra.

From research conducted concluded that management leadership in Pondok Pesantren Modern Diniyyah Pasia is demokrastis leadership that characterized by the presence of consensus agreement in determining planing, organizing and controlling.
\end{abstract}

Kata Kunci: Manajemen pendidikan, pembentukan karakter

\section{PENDAHULUAN}

Pondok Pesantren Modern Diniyyah Pasia merupakan Afiliasi dari Pesantren Modern Darussalam Gontor yang menanamkan nilai panca jiwa sebagai pembentuk Karakter anak di masa yang akan datang. Adapun Panca jiwa yang dimaksud adalah : Jiwa keikhlasan, jiwa kesederhanaan, Jiwa kesanggupan menolong diri sendiri / Mandiri, Jiwa Ukhwah Islamiyyah dan Jiwa Bebas (Imam Zarkasyi: 4 s/d 7 Juli 1965)

Adapun yang menarik adalah figur pimpinan (kyai) yang demokratis dan bersahaja, sementara di Jawa seorang
Kyai disegani bahkan diagung-agungkan. Sehingga apa yang dikatakan Kyai harus dilaksanakan tanpa ada pertimbangan dari orang lain, kalau dalam istilah lain. Perkataan Kyai itu adalah perkataan Allah, jadi sifatnya mutlak

Dari segi manajemen pendidikan, Pesantren modern terbuka bagi siapapun dan mau membuka diri, seperti adanya pelajarn umum, bahasa inggris dan lain-lain, tanpa mengabaikan pelajaran tradisional

Sementara dari segi sarana, Pesantren modern sudah mulai memiliki alat-alat 
elektronik untuk menunjang pendidikan, seperti Laptop, Infocus dan lain-lainnya, itulah salah satu dari keunikan dari pesantren modern, karena kalau dulu orang berasumsi, kalau masuk pesantren hasilnya akan menjadi ustadz, Kyai, ulama. Tapi hal itu sudah bisa dikembangkan. Tamatan pesantren bisa melanjutkan ke semua bidang tergantung kemampuan anak tersebut.

Perbedaan lain dari pesantren adalah, anak-anak diajarkan semua pelajaran yang dipakai Diknas dan kemenag, tergantung kemampuan anak-anak tersebut menerimanya. Perbedaannya denga lembaga pendidikan Umum adalah, dipesantren lebih menekankan pada penilaian akhlak yang dalam istilaha adalah karakter anak.

Adapun permasalah yang diangkat dalam tulisan ini adalah: Bagaimana Manajemen Pendidikan Pesantren Modern Dalam Pembentukan Karakter Anak? Sedangkan sub masalahnya adalah:

1. Bagaimana Manajemen Kepemimpinan Pimpinan (Kyai) Pondok Pesantren Modern Diniyyah Pasia?

2. Bagaimana Manajemen Kurikulum dan pembelajaran di Pondok Pesantren Modern Diniyyah Pasia?

3. Bagaimana Manajemen sarana prasarana di Pondok Pesantren Modern Diniyyah Pasia?

Penelitian ini adalah penelitian lapangan dengan mengunakan pendekatan kualitatif. Dalam penenelitian ini data yang hendak dikumpulkan adalah tentang Manajemen Pendidikan Pesantren Moden Diniyyah Pasia Kabupaten Agam Sumatera Barat. Dari ungkapan konsep ini dikehendaki suatu informasi yang bersifat deskriptif, karena itulah penelitian ini menggunakan pendekatan kualitatif.

Alasan penulis memakai jenis penelitian kualitatif adalah karena penelitian yang akan penulis lakukan sesuai dengan ciriciri dari penelitian kualitatif seperti yang diungkapkan Bogdan dan Biklen, yaitu:

Qualitative research has the natural setting of the direct sourcecof data and the research the key instrument, 2) qualitative research is descriptive, 3) qualitative research are concerned with process rather then simply with outcomes or product, 4) qualitative research tend the analyze their data inductively, 5) "meaning" is of essential concern to the qualitative approach. (Bogdan R and Biken Sk, :1982).

Ciri-ciri penelitian kualitatif adalah: 1) memiliki latar alamiah sebagai sumber data langsung dan peneliti adalah istrumen kunci , 2) bersifat deskriptif, 3) peneliti-peneliti kualitatif lebih memperhatikan proses dari pada hasil, 4) peneliti cenderung menganalisis data secara induktif dan 5) makna menjadi perhatian dalam pendekatan kualitatif.

Dalam penelitian tentang Manajemen Pendidikan Pesantren Modern dalam pembentukan karakter anak di Pondok Pesantren Modern Diniyyah Pasia, Ampek Angkek Kabupaten Agam Sumatera Barat, penulis ingin mendapatkan gambaran apa adanya tentang 
pelaksanaan manajemen Pesanyren Modern dalam Pembentukan karakter anak tersebut. Dalam penelitian ini, sebagaimana pendapat ahli di atas, penulis lebih mengutamakan proses dari pada hasil dan menggunakan sumber data yang bersifat alamiah.

Lokasi penelitian yang penulis pilih adalah Pondok Pesantren Modern Diniyyah Pasia, Ampek Angkek Kabupaten Agam. Sumatera Barat.

Informan menurut Kamus Besar bahasa Indonesia diartikan dengan "orang yang memberikan informasi". (W.J.S Poerwadarminta: 89)

Sedangkan infoman dalam penelitian diartikan dengan orang-orang yang dimamfaatkan untuk memberikan informasi situasi dan kondisi latar penelitian. (Moelong J. Lexy, 1995:90)

Kriteria-kriteria Informan yang baik adalah:

1. Responsif terhadap keadaan lingkungan sekitar

2. Dapat menyesuaikan diri dengan keadaan situasi pengumpul data

3. Memamfaatkan imajinasi dan kreatifitas dan memandang dunia ini sebagai suatu kebutuhan

4. Subjek mempunyai pengetahuan yang luas dan kemampuan yang tinggi

5. Mampu menjelaskan suatu informasi secara jelas. ( Moelong:94)

Berdasarkan pengertian dan keterangan di atas, informan yang penulis jadikan sebagai sumber data adalah Pimpinan Pesantren, Direktur Pesantren, wakil Pimpinan Pesantren bidang kurikulum, wakil Pimpinan Pesantren Bidang Kesiswaan, guru, orang tua peserta didik dan peserta didik yang ada di Pondok Pesantren Modern Diniyyah Pasia Kabupaten Agam. Dari sekian banyak informan, peneliti memilih Pimpinan dan wakil bidang kurikulum untuk menjadi informan utama, alasannya adalah karena dari informasi awal yang penulis peroleh melalui beberapa sumber di Pondok Pesantren Modern Diniyyah Pasia, Pimpinan Pesantren dan wakil Pimpinan Pesantren bidang kurikulum merupakan bidang yang berkaitan langsung dengan fokus penelitian peneliti.

Dalam mengumpulkan data, penulis menggunakan tiga cara, yakni dengan observasi, wawancara dan dokumentasi. Sebagaimana disebutkan Emzir, tiga cara inilah yang paling umum dan paling sering digunakan dalam penelitian kualitatatif. (Emzir, 2011:37)

Dalam melakukan observasi penerapan Manajemen Pendidikan Pesantren Modern di Pondok Pesantren Modern Diniyyah Pasia Kabupaten Agam, hal-hal yang menjadi perhatian penulis adalah pelaksanaan manajemen kurikulum sampai evaluasinya dan juga aktivitas-aktivitas harian siswa yang didesain oleh sekolah untuk tertanamnya karakter-karakter religius, disiplin dan bertanggung jawab, serta keadaan-keadaan lain yang menurut peneliti ikut memberi pengaruh dalam pembentukan karakter siswa. 
Untuk mendapatkan informasi ini, informan yang penulis pilih adalah Pimpinan Pesantren (kyai), Direktur , wakil bidang kurikulum, bidang kesiswaan, majelis guru, orang tua dan peserta didik. Proses pelaksanaan wawancara adalah dengan bertemu langsung dengan informan, baik di sekolah, di rumah atau di tempat lain yang nyaman untuk dilakukan wawancara. Selain dengan cara di atas, peneliti juga mengumpulkan data melalui teknik wawancara dengan memanfaatkan kecanggihan teknologi, seperti telepon atau HP.

Teknik pengumpulan data melalui dokumen adalah dengan mempelajari, menganalisa arsip-arsip kelengkapan kurikulum yang ada di Pondok Pesantren Modern Diniyyah Pasia, juga termasuk diantaranya adalah rencana pelaksanaan pembelajaran (RPP), silabus, daftar pelajaran, program kerja, data guru dan juga data siswa.

Setelah data yang dibutuhkan terkumpul, maka perlu dilakukan analisis terhadap data tersebut.

Dalam penulisan Tesis ini penulis menggunakan Pedoman Penulisan Tesis Progarm Pascasarjana STAIN Batusangkar 2013

\section{PEMBAHASAN}

\section{Manajemen Pendidikan Islam}

Manajemen yang berarti mengelolah merupakan terjemahan secara langsung dari kata manajement yang berarti pengelolaan, ketatalaksanaan atau tata pimpinan yang merupakan kata derivasi dara kata dhabara (mengatur) (Ramayulis, 2011: 259) yang banyak terdapat dalam Al-Qur'an seperti Firman Allah Swt pada Surat As-sajdah ayat 5 :

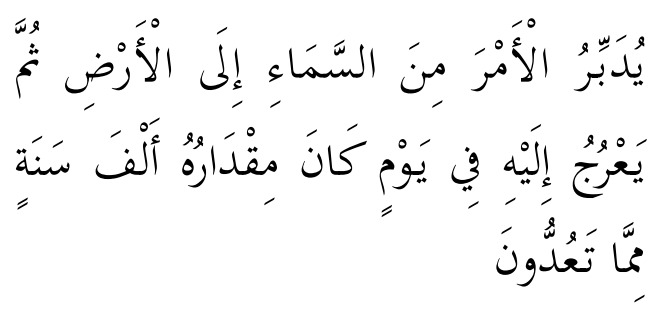

Dia mengatur urusan dari langit ke bumi, kemudian (urusan) itu naik kepadaNya dalam satu hari yang kadarnya adalah seribu tahun menurut perbitunganmu (Qs Assajdah ayat 5 )

Kepemimpinan berasal dari kata pemimpin yang artinya seorang pribadi yang memiliki kecakapan dan kelebihan, khususnya kecakapan/ kelebihan di satu bidang sehingga dia mampu mempengaruhi orang-orang lain untuk bersama-sama melakukan aktivitas-aktivitas tertentu demi pencapaian satu atau beberapa tujuan. (Kartini Kartono, 1994:181). Selain itu pemimpin dapat didefinisikan sebagai orang yang mendapat amanah serta memiliki sifat, sikap, dan gaya yang baik untuk mengurus atau mengatur orang lain.

\section{Manajemen Kurikulum}

Manajemen kurikulum yaitu suatu system pengelolaan segala aktivitas yang ada di sekolah dalam rangka memberikan pengalaman belajar terbaik bagi peserta 
didik dan dilakukan secara baik, kooperatif, komperehensif dan sistematik untuk mewujudkan tujuan pendidikan yang telah ditetapkan. Dalam pelaksanaannya, manajemen kurikulum harus dikembangkan sesuai dengan konteks Manajemen Berbasis Sekolah (MBS) dan Kurikulum Tingkat Satuan Pendidikan (KTSP).

Dalam pelaksanaan manajemen kurikulum, meskipun diberikan kewenangan luas bagi sekolah untuk berkreasi dengan adanya otonomi pendidikan, namun tetap harus dilaksanakan dan dikembangkan sesuai dengan petunjuk yang telah ditetapkan dalam aturan pelaksanaan pendidikan nasional.(Rusman, 2009:3).

Ada lima prinsip dalam manajemen kurikulum, yaitu:

1) Produktivitas,

2) Demokratisasi, penuh tanggung jawab untuk mencapai tujuan kurikulum

3) Kooperatif, dibutuhkan kerjasama positif dengan semua pihak yang terkait

4) Efektivitas dan efesiensi,

5) Mengarahkan visi, misi dan tujuan.( Rusman, 2009:4)

Secara garis besar beberapa kegiatan yang terkait dengan fungsi-fungsi manajemen kurikulum adalah:

1) Meningkatkan efesiensi pemanfaatan sumber daya kurikulum melalui perencanaan yang terencana dan efektif

2) Meningkatkan keadilan dan kesempatan kepada siswa
3) Meningkatkan relevansi dan efektivitas pembelajaran

4) Meningkatkan efektivitas kinerja guru maupun aktivitas

5) Meningkatkan efektivitas dan efesiensi proses belajar mengajar

6) Meningkatkan partisipasi masyarakat untuk membantu mengembangkan kurikulum. (Rusman, 2009:5)

\section{Sarana (Aset)}

Istilah 'sarana' dalam kamus besar Bahasa Indonesia (2001:999), berarti "segala sesuatu yang dapat dipakai sebagai alat dalam mencapai maksud atau tujuan". Dalam Peraturan Menteri Pendidikan Nasional Nomor 24 Tahun 2007 (2007:6) dinyatakan bahwa yang dimaksud dengan sarana adalah "perlengkapan pembelajaran yang dapat dipindah-pindah". Sementara itu menurut Daryanto (2005:51) menyatakan sarana adalah "alat langsung untuk mencapai tujuan pendidikan seperti: ruang, buku, perpustakaan, laboratorium dan sebagainya". Mulyasa (2004:49) mendefinisikan sarana pendidikan sebagai peralatan dan perlengkapan yang secara langsung dipergunakan dan menunjang proses pendidikan, khususnya proses belajar mengajar, seperti gedung, ruang kelas, meja, kursi, serta alat-alat dan media pengajaran.

Pengertian dari prasarana yang terdapat dalam Kamus Besar Bahasa Indonesia (2001:999) adalah sebagai "segala sesuatu yang merupakan penunjang utama 
terselenggaranya suatu proses (usaha, pembangunan, proyek dan sebagainya)".

\section{Pembentukan Karakter}

Menurut bahasa, karakter adalah tabiat atau kebiasaan. Sedangkan menurut ahli psikologi, karakter adalah sebuah sistem keyakinan dan kebiasaan yang mengarahkan tindakan seorang individu. Karena itu, jika pengetahuan mengenai karakter seseorang itu dapat diketahui, maka dapat diketahui pula bagaimana individu tersebut akan bersikap untuk kondisi-kondisi tertentu. (N.K. Singh, dkk., 2000:175)

\section{Profil Pondok Pesantren Modern Diniyyah Pasia}

Pondok Pesantren Modern Diniyyah Pasia ini merupakan pengembangan dari sekolah "Madrasah Diniyyah Pasia” yang telah berdiri semenjak tahun 1928.

Gagasan lahirnya Pondok Pesantren Modern Diniyyah Pasia ini timbul dari keinginan para alumni Madrasah Diniyyah Pasia yang bersedia mengabdikan dirinya untuk mengembangkan almamaternya guna mengantisipasi kemajuan ilmu pengetahuan dan teknologi yang semakin cepat dan pesat yang harus dihadapi dengan tidak melalaikan aqidah. Keadaan tersebut menyebabkan para alumni berinisiatif mengadakan pertemuan dengan tokoh masyarakat dan simpatisan Madrasah Diniyyah Pasia.

Pondok Pesantren Modern Diniyyah Pasia sebagai lembaga yang bergerak di bidang pendidikan Islam memiliki visi dan misi sebagai berikut:

Visi : Menjadi lembaga pendidikan Islam yang mampu menghasilkan caloncalon ulama dan cendikiawan muslim.

Misi : Membentuk santri dan santriwati yang bertaqwa, menguasai dasar-dasar pengetahuan Islam, pengetahuan umum, dan mempunyai keterampilan serta mampu mengembangkan diri sebagai calon ulama dan cendikiawan muslim.

Pondok Pesantren Modern Diniyyah Pasia melakukan sistem pengelolaan manajemen yang diatur sendiri sesuai dengan situasi, kondisi dan keadaan lingkungan pesantren dan lingkungan masyarakat di Pondok Pesantren Modern Diniyyah Pasia serta mempertimbangkan kebijakankebijakan dari pemerintah yaitu Kementrian Agama dan Departemen Pendidikan. Semua prosedur pengelolaan manajemen pesantren tidak terlepas dari nilai-nilai agama Islam. Dalam proses pengelolaan pesantren juga tidak terlepas dari istilah pelaksanaan sistem POAC (Planning, Organizing, Actuating dan Controlling). (Nashran Nazir, Wawancara, 2 Agustus 2013)

Peran kiyai dalam pendirian, pertumbuhan, perkembangan dan pengurusan sebuah pesantren berarti dia merupakan unsur yang paling penting. Sebagai pemimpin pesantren, watak dan keberhasilan pesantren banyak bergantung 
pada keahlian dan kedalaman ilmu, kharismatik dan wibawa, serta keterampilan kyai. Dalam konteks ini, pribadi kyai sangat menentukan sebab dia adalah tokoh sentral dalam pesantren. (Hasbullah, 1999:24-27, 138-161)

Pondok Pesantren Modern Diniyyah Pasia sebagai lembaga yang bergerak di bidang pendidikan Islam yang memiliki visi manjadi lembaga pandidikan Islam yang mampu menghasilkan calon-calon ulama dan cendikiawan muslim misi serta membentuk santri dan santriwati yang bertaqwa, menguasai dasar-dasar pengetahuan Islam, pengetahuan umum, dan mempunyai keterampilan serta mampu mengembangkan diri sebagai calon ulama dan cendikiawan muslim juga mampu mengikuti perkembangan ilmu pengetahuan dan teknologi.

Ruang belajar tersedia sebanyak 23 lokal dengan kondisi baik, sebenarnya lokal yang ada itu kurang memadai, karena dalam kelas banyak anak sehingga padat. Tapi kami akan selalu melengkapinya. (Dhiya Ulhaq M., Wawancara, 1 Agustus 2013)

Perpustakaan terdapat di kampus I dan kampus II terdiri dari ruang baca dan ruang buku..

Dari keadaan sarana prasarana di Pondok Pesantren Modern Diniyyah Pasia belum lengkap dan belum dapat memenuhi semua kebutuhan santri sehingga proses pembelajaran berjalan dengan kurang maksimal dan apa-apa yang dibutuhkan santri belum semuanya tersedia.

\section{Diskusi Hasil Penelitian}

Menurut Fidler "Setiap pemimpin memperlihatkan gaya yang berbeda-beda dalam melakukan banyak hal, perbedaan tersebut di antaranya terutama dalam hal melihat fungsi kepemimpinan "antara lain: a), gaya kepemimpinan yang berorientasi kepada tugas dan, b), gaya kepemimpinan yang berorientasi pada bawahan.

\section{PENUTUP}

Manajemen kepemimpinan di Pondok Pesantren Modern Diniyyah Pasia ini adalah kepemimpinan yang demokrastis ini ditandai dengan adanya musyawarah mufakat dalam menentukan Planing, Organizing dan controlling.

1. Manajemem kurikulum terhadap pembentukan karakter anak sangat berpengaruh.

2. Manajemen sarana dan prasarana yang mendukung untuk pembentukan karakter anak.

Berdasarkan kesimpulan di atas, dapat disampaikan beberapa saran diantaranya sebagai berikut :

1. Pimpinan (kyai) dapat mempengaruhi dan mampun menjalan tugas kepeimpinan dengan baik. Demi terciptanya generasi yang berkarakter 
2. Dapat menerapkan manajemen kurikulum dan pembelajaran dalam PBM dengan maksimal. Demi kelangsungan PBM yang berkualitas.

3. Agar sarana dan prasana dapat dilengkapi dengan segera, sehingga tidak ada kendala untuk melakukan aktivitas

4. Agar hasil penelitian ini dapat menjadi bahan pertimbangan bagi pengurus atau pengelolah Pesantren untuk arah yang lebih baik

\section{KEPUSTAKAAN ACUAN}

KH Imam Zarkasyi, dalam Seminar Pondok Pesantren seluruh Indonesia di Yogyakarta, Pada tanggal 4 s/d 7 Juli 1965

Alfurqan, Pemberdayaan System Pendidikan Pondok Pesantren di Indonesia, (Tesis, Suatu kajian teoritis), ( Padang: IAIN "IB" Padanag, 2002)

Ramayulis, Ilmu pendidikan Islam Kalam Mulia Jakarta. Cet. 9, 2011

Kartini Kartono, Pemimpin dan Kepemimpinan (Jakarta: Raja Grafindo Persada 1994) http://emperordeva.wordpress.com/about/ makalah-tentang-kepemimpinan/ Akses tgl.26 september 2012

Rusman, Manajemen Kurikulum, (Jakarta: Raja Grafindo, 2009), h. 3

N.K. Singh dan Mr. A.R. Agwan, Encyclopaedia of the Holy Qur'ân, (New Delhi: balaji Offset, 2000)

Bogdan $\mathrm{R}$ and Biken Sk, qualitative research for Education, An Introduction to Theory and Method, Boston: Allyn and Bacon, 1982

Moelong J. Lexy, Metode Penelitian Kualitatif, Bandung: PT. Rosdakarya, 1995

Emzir, Metodologi Penelitian Kualitatif Analisis Data, Jakarta: RajaGrafindo, 2011

Nashran Nazir, S.Pd.I, Direktur Pondok Pesantren Diniyyah Pasia, di Kampus Hasbullah, Sejarah Pendidikan Islam di Indonesia; Lintasan Sejarah pertumbuhan dan Perkembangan, ( Jakarta : PT Raja Gravindo Persada 1999)

Fidler. Fsikologi yang efektif untuk manajer. Jakarta: Mitra Utama, 1990 